40-1| 2015

Enjeux contemporains en études irlandaises - In Memoriam Paul Brennan

\title{
Why did they fight for Britain? Irish recruits to the British forces, 1939-45
}

\section{Steven O'Connor}

\section{(2) OpenEdition \\ Journals}

Electronic version

URL: http://journals.openedition.org/etudesirlandaises/4451

DOI: $10.4000 /$ etudesirlandaises. 4451

ISSN: 2259-8863

\section{Publisher}

Presses universitaires de Rennes

\section{Printed version}

Date of publication: 30 June 2015

Number of pages: $59-70$

ISBN: 978-2-7535-4082-8

ISSN: 0183-973X

Electronic reference

Steven O'Connor, « Why did they fight for Britain? Irish recruits to the British forces, 1939-45 », Études irlandaises [Online], 40-1 | 2015, Online since 30 June 2017, connection on 19 April 2019. URL : http:// journals.openedition.org/etudesirlandaises/4451 ; DOI : 10.4000/etudesirlandaises.4451 


\title{
Why did They Fight for Britain? Irish Recruits to the British Forces, 1939-1945
}

\author{
Steven O'Connor \\ Trinity College Dublin
}

\begin{abstract}
In spite of Ireland's neutrality tens of thousands of Irish people fought in the British forces during the Second World War. Previous studies of these transnational volunteers have focused largely on government policies towards the recruits and on ascertaining an accurate figure for the number of Irish people in the wartime British forces. However, there remain important questions about these Irish recruits. This article examines their social backgrounds and their motives for enlisting. It concludes by assessing the significance of Irish recruitment within the wider context of the contribution to Britain's war effort from members of the British Commonwealth.
\end{abstract}

Keywords: Anglo-Irish relations, Second World War, Irish soldiers, British army

\section{Résumé}

Malgré la neutralité de l'Irlande, des dizaines des milliers d'Irlandais ont combattu dans les forces armées britanniques pendant la Seconde Guerre mondiale. Les dernières études sur ces volontaires transnationaux se concentrent principalement sur les politiques gouvernementales encadrant ces nouvelles recrues et sur le dénombrement précis des Irlandais qui servaient dans les forces britanniques pendant la guerre. Pourtant, des questions importantes au sujet de ces recrues irlandaises restent encore sans réponse. Cet article examine le milieu d'origine et les motivations de ces Irlandais. Enfin, l'importance de ce recrutement dans le contexte de la contribution des nations du Commonwealth britannique à l'effort de guerre de la Grande-Bretagne est évaluée.

Mots clés : relations irlando-britanniques, Seconde Guerre mondiale, soldats irlandais, armée britannique

The centennial commemorations of the outbreak of the First World War have inspired much scholarly research on various aspects and consequences of Ireland's involvement in that war. However, the unrelenting focus on the First World War among Irish historians has meant that other conflicts no less significant for Ireland and its peoples have received comparatively little attention. The 8 May 2015 marks 70 years since Nazi Germany surrendered to the Allied powers in the Second World War. For the Irish government the end of the war in Europe signal- 
led the miraculous survival of Ireland (or Éire) as a small, independent and democratic state which had avoided the fate of many other European neutrals. Yet in 1945, while Irish politicians congratulated themselves on keeping Ireland out of the global conflagration, British civil servants in the Dominions Office estimated that 42,665 men and women from neutral Ireland had served in the British forces during the Second World War ${ }^{1}$. Recent research suggests that the real figure was about 70,000. Who were these transnational volunteers and why did they decide to join up?

In the 70 years since the war ended there has been little scholarship on the "neutral" Irish who fought for Britain. Attempts to rectify this began over two decades ago with the publication of popular accounts of Irish people involved in the war by Richard Doherty and Myles Dungan, among others ${ }^{2}$. Scholarly analysis, however, has largely focused on other aspects of Ireland's relationship to the Second World War, such as high diplomacy, censorship, cultural development and economic challenges ${ }^{3}$. The collection and archiving of 57 oral history interviews with Irish veterans by the Volunteers Project in University College Cork in the late 1990s has gradually attracted more scholarly research on the Irish in the British forces ${ }^{4}$. While some of this research has examined Irish motives for joining up, the main focus has been on government policies towards these recruits and on ascertaining an accurate figure for the number of Irish people in the British forces during the war. Doubts have always existed about official British estimates for Irish recruits due to the fact that some estimates were based on records of last address before enlistment rather than place of birth. Research by Richard Doherty, Yvonne McEwen and Brian Girvin has revealed that the total number of recruits from Éire was about $70,000^{5}$. All of this scholarship has significantly

1. The National Archives, UK [TNA], Dominions Office [DO] 35/1230, J. Maffey note, 12 March 1945.

2. R. Doherty, Clear the Way! A History of the 38th (Irish) Infantry Brigade, 1941-1947, Dublin, Irish Academic Press, 1993; R. Doherty, Irish men and women in the Second World War, Dublin, Four Courts Press, 1999; M. Dungan, Distant Drums: Irish soldiers in foreign armies, Belfast, Appletree Press, 1993. Kevin Myers' journalism over three decades has also done a great deal to raise awareness of the Irish in the British forces.

3. R. Fisk, In Time of War: Ireland, Ulster and the price of neutrality 1939-45, London, André Deutsch, 1983; D. Ó Drisceoil, Censorship in Ireland 1939-1945: Neutrality, Politics and Society, Cork, Cork University Press, 1996; D. Keogh and M. O'Driscoll (eds), Ireland in World War Two: Neutrality and Survival, Cork, Mercier Press, 2004; C. Wills, That Neutral Island: A History of Ireland during the Second World War, London, Faber and Faber, 2008; B. Evans, Ireland during the Second World War: Farewell to Plato's Cave, Manchester, Manchester University Press, 2014.

4. A. McElwaine, "The oral history of the Volunteers", B. Girvin and G. Roberts (eds), Ireland and the Second World War: Politics, Society and Remembrance, Dublin, Four Courts Press, 2000, p. 107-20; J. Jenkins, "This a private shindy or can any bloke join in?': Why neutral Irish volunteered for service in the British forces during the Second World War", Irish Sword, vol. 28, no. 114, winter 2012, p. 419-453; B. Kelly, Returning Home: Irish ex-servicemen after the Second World War, Dublin, Merrion, 2012.

5. R. Doherty, In the Ranks of Death: the Irish in the Second World War, Pen \& Sword, 2010, p. 26-30; Y. McEwen, "Deaths in the Irish Regiments 1939-1945 and the extent of Irish volunteering for the British Army", Irish Sword, vol. 24, 2004-5, p. 81-98; B. Girvin, The Emergency, London, Pan Books, 2007, p. 274-275. 
advanced the study of Irish people in the Second World War, but there remain important questions about who these recruits were, why they enlisted and what significance should be attached to the figure of 70,000 . Thus, based on a wide range of primary sources this article attempts to shed light on the social backgrounds that the Irish recruits came from, their motives for fighting for Britain and finally, it assesses the significance of this Irish recruitment by comparing it to the contribution of other British dominions.

\section{Who became a recruit to the British armed forces?}

Irish recruitment to the British forces did not begin with the outbreak of war in September 1939; in fact Irish people had not ceased to join the British forces either before or after southern Irish secession from the United Kingdom in 1922. During the interwar period Irish soldiers comprised about five per cent of the British army's manpower and while there are no returns of officers' nationality, anecdotal evidence suggests a similar proportion for the Irish in the officer corps $^{6}$. In examining the social backgrounds of these Irish recruits differences arise between those who obtained officer commissions and those who joined the enlisted ranks.

Irish people who became officers in this period were not representative of independent Ireland; they were an elite and their backgrounds resembled those of English, Scottish and Welsh officers. In recruiting officers the British military authorities were informed by an elitist attitude which dictated that only young men who had been educated in a recognised "public school" had the necessary leadership qualities to become effective officers. The result was that the upper classes dominated the officer corps while the working class and lower middle class were expected to provide "the other ranks", i.e. the private soldiers and non-commissioned officers. This system of officer selection was reformed during the war; however, the majority of wartime Irish officers continued to come from uppermiddle-class backgrounds. A recent study of Irish officers based on a sample of 1,000 suggests that among the Irish in the British officer corps a slight majority were Protestant, that they were at least 19 or 20 years old, that they tended to come from urban areas and prosperous agricultural districts (Dublin, Cork, Tipperary, the midlands and east coast counties were well-represented), that a majority were educated at a boarding school in Ireland or Britain and that their fathers were likely to be officers, doctors, engineers and company directors ${ }^{7}$.

\footnotetext{
6. For the Irish proportion in the army during the interwar period see the parliamentary command papers, General Annual Report on the British Army.

7. S. O'Connor, Irish Officers in the British Forces, 1922-45, Basingstoke, Palgrave Macmillan, 2014, p. 15-29.
} 
The Irish in the enlisted ranks, on the other hand, came from more modest backgrounds and were more representative of the Irish population. They were predominantly Catholic and, as this article will later show, many were underage being only 16 or 17 years old ${ }^{8}$. During the 1930s many of the Irish recruits to the British forces were agricultural labourers who were struggling to earn a sufficient income in an Ireland severely affected by the depression and the trade war with Britain. This is reflected in the fact that the largest portion of Irish recruits came from counties Dublin, Kildare, Wexford, Tipperary and Cork - these were the counties where the most farm labourers worked and the ones most affected by the slump in agricultural prices. Indeed, some farmers complained of losing workers who preferred to leave the country and join the British army due to the higher pay'. After the outbreak of the Second World War the attractions of the British forces - stable employment and better pay - were outweighed by the dangers injury and death. Therefore, one observes a change in the social profile of Irish recruits to the British enlisted ranks: fewer economic migrants joined up, but the attractions of war service - action, adventure, travel - ensured a more diverse recruitment from Irish society than would be the case in peacetime. Wartime recruits came from a wide array of counties (both urban and rural areas) and typical backgrounds included labourers, skilled workers and those from lowermiddle-class backgrounds, such as the sons of shopkeepers and tradesmen ${ }^{10}$.

\section{Volunteering: motives and influences}

Why did they fight for Britain? There is no simple answer to this question and perhaps there were as many reasons as there were recruits. Yet some common motives emerge from the testimony left to us by this generation through published and unpublished memoirs, diaries and interviews.

Many Irish recruits were influenced by a family tradition of serving in the British forces which pre-dated Irish independence. John Finnerty followed in his father's footsteps by joining the British army in the 1930s. His father had served for 21 years in the same army, including service in France during the First World War, where he was severely wounded. Yet even this experience did not shake his

8. This continued a practice which was prevalent during the First World War. Officially, the lower age limit for enlistment was 18, but there were thousands of under-age boys who were accepted into the British army without even providing a birth certificate. Indeed, one of the youngest soldiers to die in that war was John Condon from Co. Waterford at the age of 15.

9. O'Connor, op. cit., p. 21-22.

10. This analysis of Irish people in the enlisted ranks is based on data from interviews with Irish veterans in the Volunteers Project Archive [VPA], University College Cork [UCC], the Imperial War Museum's sound archive [IWMSA] and material from Faugh-a-Ballagh: the Regimental Gazette of the Royal Irish Fusiliers, vol. 33, no. 149 (January 1939). 
father's belief in soldiering as a worthwhile profession. "For as long as I could remember", Finnerty wrote,

he spoke in very encouraging terms about the Army as a worthwhile career [...] Most of the ex-soldiers, in passing information to each other about their son's intention of becoming a soldier, seemed to regard it as a feather in their cap; only a very few advised their boys to stay at home. As far as they were concerned it was the Army first, last and always. To a young man who heard very little else it was only natural that he was influenced by what could truly be regarded as the best form of recruitment ${ }^{11}$.

Dublin native Michael Connell came from a similar background: his uncles fought in the First World War and his older brother served in the army of the Irish Free State before joining the British army. In the 1930s his brother used to return home on leave and recount his travels in Africa and Palestine. As a boy this impressed Michael greatly and he started to believe that "it was a great thing to be a soldier". When the Second World War broke out Michael's brother was recalled from the reserves and he asked Michael to go with him because "it wasn't just for the love of the king or country but it, the British army, was somewhere to be, you'd see a bit of the world and as your father would say they'd make a man out of you ${ }^{12}$. Michael succeeded in joining up at the age of 16 . He survived the war but his brother did not.

Other recruits were swept into the British forces on the tantalising prospect of adventure in distant lands. In 1941 Majella, a nurse from county Kildare, joined the Queen Alexandra's Imperial Military Nursing Service. Majella expected the war to be over in a year: she was eager "to get into it before it ended". As a young person during the war, she explained, "the only thing you're thinking about is where you're going to go and all the excitement that goes with it". When she was posted to India instead of France as expected, "that was a surprise, but of course more excitement ${ }^{13}$ ". In her perception of the war as offering opportunities for excitement and adventure Majella was far from exceptional. Other Irish recruits to the British forces contrasted the prospects for adventure in the war with the boredom of civilian life in Ireland. Arthur Smith joined the Royal Air Force (RAF) in 1943: "Dublin was a very boring, small place then, you know, I was itching to get away ${ }^{14}$." Moreover, another Irish woman, who joined the Auxiliary Territorial Service in 1941, wrote in her diary:

11. J. Finnerty, All Quiet on the Irrawaddy, Bognor Regis, New Horizon, 1979, p. 7.

12. UCC, VPA, M. Connell.

13. Nurse Majella [pseudonym] quoted in O'Connor, op. cit., p. 102.

14. UCC, VPA, A. Smith. 
Even if Éire is staying neutral, I am not. I don't want to be left out of war shaking events - the Battle of Britain decided me on that - and I do want to be in uniform driving all sorts of exciting people about instead of being cooped up in a ghastly boring office behind the Four Courts ${ }^{15}$.

Some recruits, like Don Mooney, even made the frank admission that at the time they were not interested in the politics of the war: "no moral reason, we didn't know much about Hitler or anything, it was just excitement ${ }^{16}$."

A frequently cited motive for joining the British forces was the need to find employment. James Kelly, from Bray, Co. Wicklow, explained the difficulty of trying to survive in a depressed economy: "Well there was no work in southern Ireland [...] I was a painter and decorator but things were pretty rough [...] and I decided to join up ${ }^{17}$ ”. Similarly, Dan Horgan left school at the age of 17 and was "walking around Cork City for almost a year" seeking work; he eventually joined the $\mathrm{RAF}^{18}$. However, if these recruits only wanted to improve their economic situation they could have earned higher wages by following other Irish migrants into the booming British war industries; what is more, this work involved less risk to life and limb than service in the British forces. In reality, recruits who mentioned the economic motive generally had additional motives pushing them towards the British military. For example, Thomas Meehan from Dublin was 16 years old when he joined the Royal Ulster Rifles and he recognised a number of factors influencing his decision to join up: "Young, innocent, no sign of employment, looking for adventure ${ }^{19}$." Moreover, about 4,500 soldiers of the Irish army deserted during the war and in their investigations of why many of these deserters joined the British forces Irish officials tended to regard them as mercenaries, concluding that the higher rate of pay and family separation allowance attracted the deserters to the British army ${ }^{20}$. Yet, the evidence collected in these investigations suggested that there was a multiplicity of reasons. In Captain Fitzpatrick and Captain O’Brien's report of their interview with Private Daniel Rooney, a deserter who was arrested when returning to Ireland, his motives were identified as:

Partly economic. [He] was expecting to get a dependent's allowance of 21/- per week. Appeared to be an adventurous youth who was fond of a good time. He said there was a lack of appreciation for a soldier in

15. R. Lambkin, My Time in the War: an Irishwoman's Diary, Dublin, Wolfhound Press, 1992, p. 5.

16. Steven O'Connor, interview with Captain D. Mooney, 22 January 2010.

17. IWMSA, accession no. 20007, J. Kelly.

18. UCC, VPA, D. Horgan.

19. UCC, VPA, T. Meehan.

20. National Archives of Ireland [NAI], Department of the Taoiseach [DT], S6091A, memorandum by Minister for Defence, "Assistance being afforded to Irish citizens to enlist in the British Army," 6 May 1941. 
this country. In England on the other hand, there were free pictures, bus rides, dances, and glamorous girls hero-worshipping the soldiers ${ }^{21}$.

Corporal John McDermott admitted that he deserted the Irish army because his pay was not enough to support his family, but he also expressed the opinion that men in the Irish army were "harshly treated" by officers and that food was "badly cooked". Finally, it was suggested that another deserter had joined the British army because it paid him "17/6d. per week", but it was noted that his deceased father had also served in the British army ${ }^{22}$.

Throughout the war the Protestant community in southern Ireland proved a reliable source of manpower for the British war effort. Sydney James Gray came from a "military family" who were "very pro-British"; several of his relations had served in the British army. He evoked the pervasiveness of military service within the Protestant community in Bray, Co. Wicklow: "nearly all my friends were in the RAF or the army or navy, nearly all my class - the boys - I would say that 90 per cent of them joined up, one way or the other, as soon as they were $18^{23}$." Indeed, some recent research suggests that the Protestant community in Ireland was significantly over-represented in the British forces. In the late-1930s five per cent of the population belonged to the Church of Ireland, the largest Protestant denomination in the country, yet Jeremy Jenkins, in an examination of the 57 interviews of the Volunteers Project, found that 25 per cent of the interviewees were from the Church of Ireland ${ }^{24}$. Moreover, O'Connor collected a sample which focused exclusively on the officer corps; he found that out of 459 Irish officers who joined the wartime British forces 50.5 per cent were Protestant ${ }^{25}$.

The explanation for this over-representation is not difficult to find. Ever since the Elizabethan period, when a small yet powerful Protestant community was planted in Ireland, this minority had looked to Britain both for protection and for opportunities for imperial service. After southern Irish secession from the United Kingdom in 1922 Irish Protestants continued to regard themselves as being part of the British empire and, therefore, had a strong sense of allegiance to the king. However, their children - the generation which would come of age during the Second World War - grew up in an increasingly independent Ireland and some developed multiple loyalties and identities. The resulting confusion was illustrated in the family identity of Kildare-native Randal Sadleir:

21. Irish Military Archives, EDP 13/5, Captain P. Fitzpatrick and Captain M. O’Brien to G2 Branch [Military Intelligence], Department of Defence, 15 November 1941.

22. Ibid.

23. IWMSA, accession no. 30391, S. J. Gray.

24. W. Vaughan and A. Fitzpatrick (eds), Irish Historical Statistics: population, 1821-1971, Dublin, Royal Irish Academy, 1978, p. 49; Jenkins, op. cit., p. 439.

25. O'Connor, op. cit., p. 28. 
[I was] acutely aware of the contradictions in my blood. Father, stern scion of the Cromwellian invader, the colonial conqueror; Mother, brown eyed Celtic beauty, a Kenny from Killeshandra [...] we were Irish and not Irish; sometimes unkindly called West Britons, yet certainly never English, British perhaps, Protestant certainly ${ }^{26}$.

In his memoirs Sadleir listed among his heroes Protestants who had distinctly Irish identities, such as Henry Grattan and Charles Stewart Parnell, while also recognising that the Protestant Ascendancy had produced some of Britain's most successful military leaders, such as the Duke of Wellington, Admiral David Beatty and Field Marshal Bernard Montgomery. On the other hand, Sadleir was typical of the sons of middle-class Protestant families who had strong family and educational ties to England: for them, as Don Mooney put it, joining up "was something that was taken for granted ${ }^{27}$." Officer recruits such as Sadleir, Sidney Watson and Brian Inglis had attended British public schools and knew friends who were joining up or were enduring the "Blitz $\mathrm{z}^{28}$ ". In such families, where feelings of loyalty still ran high, it was common to regard men of military age who stayed in neutral Ireland as "white feathers" (cowards). Therefore, peer pressure and the feeling that it was an obligation were intense: "Strange as it may seem now, it seemed inconceivable to me then not to join up as soon as possible, since all my friends and relations were there, and some had already been killed or wounded ${ }^{29}$ ", Sadleir recalled. It was not just Protestant men who were affected by peer pressure. Maureen Deighton, from Askeaton, Co. Limerick, became a radar operator in the Women's Auxiliary Air Force. In 1940 she was attending a domestic science college in Britain and she recalled that the only thing her friends talked about was "the war, the war, the war and we must join up and do this ${ }^{30}$." When asked why she joined, she replied: "All my friends were doing it, it was the done thing [...] it wasn't that one was madly patriotic or anything like this... anyway if I'd stayed in England I'd have been called-up."

Some Irish recruits also believed that by joining the British forces they were defending Ireland too, as they could not imagine Hitler leaving the country alone once Britain had been defeated, particularly since British territory extended to the north of Ireland. In discussing his reasons for joining the Royal Inniskilling Fusiliers in 1943, the aforementioned Randal Sadleir made this point clear: "Quite apart from family traditions and loyalty to the Crown, it seemed obvious that if

26. R. Sadleir, Tanzania: Journey to Republic, London, Radcliffe Press, 1999, p. 3-4.

27. Steven O'Connor, interview with Captain D. Mooney, 22 January 2010.

28. S. Watson, Furnished with Ability: the Lives and Times of Wills Families, Salisbury, Michael Russell, 1991, p. 234; B. Inglis, West Briton, London, Faber and Faber, 1962, p. 36.

29. Sadleir, op. cit., p. 13.

30. UCC, VPSA, M. Deighton. 
England lost the war, the Germans would soon occupy Ireland and the dark ages would return ${ }^{31}$." Similarly, Denis Murnane, a Catholic studying at Trinity College whose father had served in the Great War, answered the Irish government's appeal for volunteers and joined the Local Security Force. However, as Ireland's position became more perilous, he was forced to conclude that if the Germans did invade "what are we going to fight them with? So I decided I would rather fight with what little the British had so [I] went up to Belfast and joined the RAF ${ }^{32}$ ". Yet this is not to take away from the 40,000 Irish volunteers who contributed directly to the country's defence by opting for service with the Irish army during the "Emergency". It is likely that their enthusiastic response to the regular army's recruitment drive, in addition to the 150,000 who joined the Local Security and the Local Defence Forces, helped convince the warring powers that an invasion and occupation of Ireland would incur a heavy price that would outweigh any potential strategic advantage ${ }^{33}$.

\section{橉 The Irish contribution and the Commonwealth context}

In September 1939 Australia, New Zealand, South Africa and Canada all joined Britain in declaring war on Germany. The majority of citizens in these selfgoverning British dominions still felt strong ties to the "Mother country", therefore it never occurred to their governments to stay out of the war. Only in South Africa was there some hesitancy until Jan Smuts became prime minister, replacing the anti-British government of Barry Hertzog. Ireland - still technically a member of the British Commonwealth - was the sole dominion to declare neutrality. This was unsurprising considering that the Irish War of Independence (1919-21) was still within living memory, although it is important to acknowledge that in several key respects Irish "neutrality" clearly favoured Britain: the Irish government did nothing to stop tens of thousands of Irish citizens from joining the British forces, the British and Irish military staffs maintained close contact in order to plan against a possible German invasion of the island, and important intelligence was regularly shared with the Allied powers ${ }^{34}$. Taoiseach Éamon de Valera's decision to keep Ireland officially neutral has been regarded by Irish historians as a logical expression of Irish independence and as a prudent move to avert civil war, considering that there remained a significant republican minority in the state who were

31. Sadleir, op. cit., p. 13. See also UCC, VPSA, Captain J. Jermyn; Watson, op. cit., p. 234 and IWMSA, accession no. 14594, W. Magrath.

32. Murnane quoted in O'Connor, op. cit., p. 32.

33. See M. Kennedy and V. Laing (eds), The Irish Defence Forces 1940-1949: the Chief of Staff's Report, Dublin, Irish Manuscripts Commission, 2011.

34. R. Fanning, Independent Ireland, Dublin, Helicon, 1983, p. 120-125. 
violently anti-British ${ }^{35}$. Interestingly, many Irish volunteers agreed with the Irish state's policy of neutrality ${ }^{36}$. In explanation some cited the above reasons while others believed that it was militarily wise as Ireland's unpreparedness, particularly for an air attack, meant that to enter the war would invite a catastrophe and still others believed simply that, as David Baynham asserted, neutrality "kept all my friends and relations reasonably safe I thought ${ }^{37}$. Based on the available primary sources it appears that only a minority of the volunteers were opposed to Irish neutrality. These volunteers generally served in the Royal Navy and believed that the use of southern Irish ports would have made a significant difference in the struggle to sink German submarines operating in the Atlantic Ocean and protect the convoys of merchant ships from the United States ${ }^{38}$.

In spite of neutrality, as we have already seen, about 70,000 southern Irish volunteers joined the British armed forces during the Second World War. How does this unofficial Irish contribution compare to the contributions of other self-governing dominions that were actually in the war? Each of the dominions recruited and organised considerable land, sea and air forces. These were used for their own national defence and large portions were also sent overseas, in order to bolster the British war effort in the various theatres of war. Thus, the Commonwealth's contribution in several spheres produced impressive results. In the air war the establishment of the Empire Air Training Scheme and associated schemes enabled 168,000 British and Commonwealth aircrew to be trained in the dominions. In the battle of the Atlantic the Royal Canadian Navy (RCN) played a considerable role, as reflected in the enormous expansion of the RCN from 13 ships in 1939 to 428 ships by war's end ${ }^{39}$. Moreover, in the Allied campaign to liberate northwest Europe over 327,000 dominion troops served under the British army's command $^{40}$. Overall, about 330,000 Canadians, 127,000 Australians, 70,000 South Africans and 55,000 New Zealanders served in land, sea and air

35. See D. Ferriter, "Denigrating neutrality during Second World War has become fashionable: historical understanding of the Emergency has diminished", Irish Times, 11 May 2013, p. 3; E. O’Halpin, "Irish neutrality in the Second World War", N. Wylie (ed.), European Neutrals and Non-Belligerents during the Second World War, Cambridge, Cambridge University Press, 2002, p. 283-303.

36. Though there is evidence that by 1944 a growing number of volunteers thought that Ireland should enter the war, as the danger of German invasion had now passed and they feared that the continuation of neutrality might provoke the Allies into punishing Ireland with economic and political isolation after the war: TNA, War Office [WO] 204/714, memo, "Irish troops mail, 31 Mar - 13 Apr 44”, 17 April 1944.

37. UCC, VPA, B. Bolingbroke, M. D’Alton, J. Drumm and D. Baynham.

38. What made this situation even more frustrating for many in the Royal Navy was the fact that these "Treaty ports" had been under British control until as recently as 1938, when British Prime Minister Neville Chamberlain had handed them over to the Irish government as part of the Anglo-Irish Agreement to end the "Economic War" between the two countries.

39. O'Connor, op. cit., p. 39-40.

40. TNA, WO 73/160, General return of the strength of the British Army on the 31 March 1944. 
forces under British command during the $\operatorname{war}^{41}$. When we compare these figures as proportions of their respective populations, Irish participation holds up well. For example, the 70,000 Irish volunteers represented 2.4 per cent of southern Ireland's population of 2.9 million. Therefore, Ireland's manpower contribution to the British forces was proportionately higher than that of South Africa (0.7 per cent of its population) and Australia (1.8 per cent), and slightly less than Canada's (2.8 per cent) and New Zealand's (3.3 per cent). This is remarkable considering that southern Ireland was officially neutral during the war.

In spite of southern Ireland seceding from the United Kingdom and organising its own defence forces, the period 1922-45 saw the continuation of the shared military tradition of Britain and Ireland, a tradition which was particularly evident during the Second World War. Irish men and women from all classes and religions continued to join the commissioned and enlisted ranks of the British forces: those who became officers generally came from upper class families as indicated by their social and educational backgrounds, while those who joined the enlisted ranks came from a variety of working and middle class backgrounds, ranging from impoverished labourers, unemployed school-leavers and farmers' sons to skilled workers, clerks and salesmen. In addition, there was a disproportionate Protestant presence among the Irish recruits which illustrated the continued importance of the British connection to the small Protestant community in southern Ireland. Examining the testimonies of the recruits we find that a few were idealistic, some were patriotic, many were young and naïve. Their decision to join up sometimes derived from a romanticised understanding of what war was like, while for others it came after long consideration of the consequences. In short, there was a complex mixture of motives among Irish recruits who fought for Britain, ranging from loyalty, peer pressure, family tradition and idealism to the need for employment, the fear of missing all the excitement and the appeal of travel.

Finally, it is estimated that about 70,000 Irish people served in the British forces during the war. Compared with the contributions from other Commonwealth countries Ireland contributed its fair share, in spite of the state being neutral. How, therefore, do we reconcile Éire's neutrality with the active involvement in the war of thousands of its citizens? In spite of Taoiseach de Valera's project to revise the Anglo-Irish Treaty and assert Ireland's sovereignty and independence, it is clear that his foreign policy was informed by an appreciation of

41. Ibid.; H. Nelson, Chased by the Sun: the Australians in Bomber Command in World War II, Crows Nest, Allen and Unwin, 2006, p. 44; various country profiles in I. Dear and M. Foot (eds), The Oxford Companion to World War II, Oxford, Oxford University Press, 2001. Note that figures for naval personnel under British command are incomplete for Australia, Canada and South Africa. 
the many interconnections - geography, history, military, trade, employment between Ireland and Britain. His awareness of this geo-political reality ensured that neutrality was slanted in favour of Britain: the Irish government would not impede any individual intent on leaving the state to join the British forces and it would secretly co-operate with the Allies when required. Consequently, when the war ended the government well understood that a significant factor in Ireland's survival had been the country's proximity to Britain and the consequent protection afforded by Allied air and naval power. However, for domestic political reasons in his broadcasted address to the nation de Valera preferred to present survival as a national achievement based on the Irish defence forces and "the united efforts of our people", while carefully avoiding any acknowledgement that Irish people in the British forces had also helped to protect Ireland ${ }^{42}$. It was only in May 2013, precisely 68 years after the war in Europe ended, that the Irish state finally acknowledged the importance of those who had fought for Britain: "These individuals contributed in no small part to the allied victory against tyranny and totalitarianism. Their efforts, in an indirect way, also contributed to the safety of their home country. If the United Kingdom had fallen to the forces of Nazi Germany, the same fate would almost certainly have been visited on this island, with all of the consequences that would have gone with it ${ }^{43}$."

42. See de Valera's speech in reply to Churchill's victory broadcast, Irish Press, 17 May 1945, p.1.

43. Closing statement by minister for defence, Alan Shatter TD, on the Defence Forces (Second World War Amnesty and Immunity) Bill 2012, Dáil Eireann, 7 May 2013 [http://www.defence.ie]. Shatter's speech went even further than Taoiseach John Bruton's tribute to the Irish volunteers in April 1995. 